\title{
国における情報データベースの構築とその活用
}

\author{
岡 本 悦 司*

\section{Development of the National Database by the Government and its Potential for Pharmacoepidemiology}

\author{
Etsuji OKAMOTO* \\ *Section of Business Administration, Department of Management Sciences, \\ National Institute of Public Health \\ 2-3-6 Minami, Wako, Saitama 351-0197, Japan
}

\begin{abstract}
$\langle$ Abstract $\rangle$
As the number of electronically submitted health insurance claims increases, so does the potential for the effective use of such valuable health data to improve quality health care. The Ministry of Health, Labor \& Welfare (MHLW), thanks to the IT reform initiative in 2006 calling for creation of a national database (NDB) and its effective use for epidemiological studies, is developing NDB containing health insurance claims data as well as health checks and guidance data individually linked by encryption techniques. Procurement of the software (system development) and the hardware will be completed by the end of FY2008, and gradual collection of data will start in FY2009. In the first phase (FY2009-10), the analysis of the evaluation of Health Care Cost Containment Plans (HCCCP) will be the top priority and the economic evaluation of health checks and guidance may pose methodological challenges. In the second phase (FY2011-), after a full on-line submission of health insurance claims, MHLW will start to publish the findings of the analysis. Although the governing law limits the purpose of NDB to "development, implementation and evaluation of HCCCP", a report by the committee studying the use of health insurance claims data for the improvement of quality health care called for wider use of NDB for public interests in February 2008. Also, JSPE submitted a statement to the Minister in late 2007 calling for the use of NDB for pharmacoepidemiological purposes. For the opinions and demands of JSPE to materialize, continued support and effort from the members is greatly appreciated.
\end{abstract}

Key words : national database, health insurance claims, MEDIAS, drug utilization review, online submission

\section{レセプト電子化の現状}

レセプト電子化は着実に進展している。2009 年 1 月の支払基金受付状況 (2008 年 12 月診療分)
によると, 2008 年 4 月よりオンライン請求が義務 づけられた 400 床以上病院では, 件数での電子化 率は $95.5 \%$ (オンライン化率も同じ), 調剤薬局 の電子化率 $95.6 \%$ (オンライン化率は $37.7 \%$ ) に

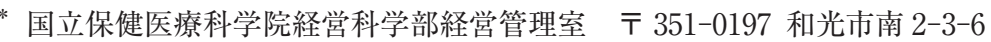


達した ${ }^{1)}$. 2011 年度までの完全オンライン化は十 分達成可能であり, そのデータの有効活用のため の体制構築が焦眉の課題となっている.

\section{調剂電子レセプト収集}

保険局調査課は 1986 年より MEDIAS（Medical Information Analysis System) を運用し 1998 年よりインターネット上でも提供している。これ は審査支払機関からレセプトの集計データ（個票 ではなく）を月単位で収集し月報として提供する もので，現在では医療機関の種類ごとの医療機関 MEDIAS も提供されている。これらは月単位の 医療費の変動を迅速に把握できるメリットがある が,レセプト個票デー夕を収集するものではなく， また傷病名も含まれていないという限界があっ た.レセプトが紙媒体のままでは迅速な個票デー 夕の収集は不可能だった。

調剤レセプトの急速な電子化を受けて, 2004 年 10 月より電子化された調剂レセプトの個票デー 夕収集が開始され，2008 年 3 月分より調剂 MEDIAS として公表されるようになった [http:// www.mhlw.go.jp/topics/medias/c-med/2008/03/]. 公表されているのは, 薬効分類別の薬剤点数等の 集計デー夕のみであるが, 収集されるデー夕内容 は患者や処方保険医氏名を除くほとんどすべて となっており (平成 18 年 5 月 31 日保調発第 0531002 号), 薬荗使用実態調査としては十分活用 できる余地がある（図 1).

以前の MEDIAS では収集されるのは個票デー タではなく集計データだけだったので統計法の適 用は受けていなかったが，調剤レセプトの個票を 収集するようになったことから 2006 年 6 月より 統計法に基づく届出統計（「医療費の動向」調査） となった。旧統計法の下では, 統計目的に収集さ れたデー夕の目的外使用は禁じられていたが, 2009 年度から新統計法が施行されると, 二次利用 の可能性が広がる (新統計法第 32 条)。ただ，医 科レセプトとのリンクなしに調剤レセプトだけで は医薬品使用実態としては役立っても薬剤疫学的 な活用として限界があると考えられる。

\section{レセプト情報・特定健診等 データベースシステム}

2006 年 1 月 IT 戦略本部が決定した IT 新改革 戦略において「レセプトデータの学術的 (疫学的) 利用のため, データベースの整備及び制度的対応 を 2010 年度までに実施する」方針が示され, 2007 年 3 月厚生労働省が示したグランドデザインにお いて「2008 年度末までに体制構築, 2009 年度から 収集・分析を段階的に実施, 2011 年度から厚生労 働省において全国規模での収集，分析・公表を実 施」する方針が示された.

このデータベースシステムはレセプト情報・特 定健診等データベースシステム (仮称, 以下 NDB) と呼ばれるが，その法的根拠は統計法ではなく高 齢者医療確保法である。すなわち「医療費適正化 計画の作成，実施及び評価のため」国は健診とレ セプトデータを保険者から収集する権限が付与さ れている(第 16 条 1 項)。そこでIT 新改革戦略 で示された学術的利用を促進するため 2007 年 7 月から「医療サービスの質向上のためのレセプト 情報等の活用に関する検討会」が設置され 2008 年 2 月報告書が出された ${ }^{2)}$. NDB は医療費適正 化計画への活用を主目的としつつも, 新統計法に 準じた扱いによって学術利用が進められると予想 される。

\section{NDB の進渉状況}

$\mathrm{NDB}$ 構築は, 保険局総務課保険システム高度 化推進室が中心となって進められるが, その調達 は専門的知識が必要であることから 2007 年 8 月 「入札仕様書 (案) の作成及び作成のための技術的 支援」をアクセンチュア社が受注し，2008 年 5 月 には調達計画書が公表されシステムの全容が明ら かになった（図 2). 以下，公開されている調達計 画書ならびにシステム開発, 機器調達そして運 用・保守それぞれの仕様書より要約する.

システムは支払基金や国民健康保険団体連合会 に設置される「匿名化・提供システム」と厚生労 働省に設置される「取込・定型資料作成等システ ム」から成り, 調達は, ハードウェア (機器構築), 
薬骫疫学 Jpn J Pharmacoepidemiol, 14(1) June 2009：49

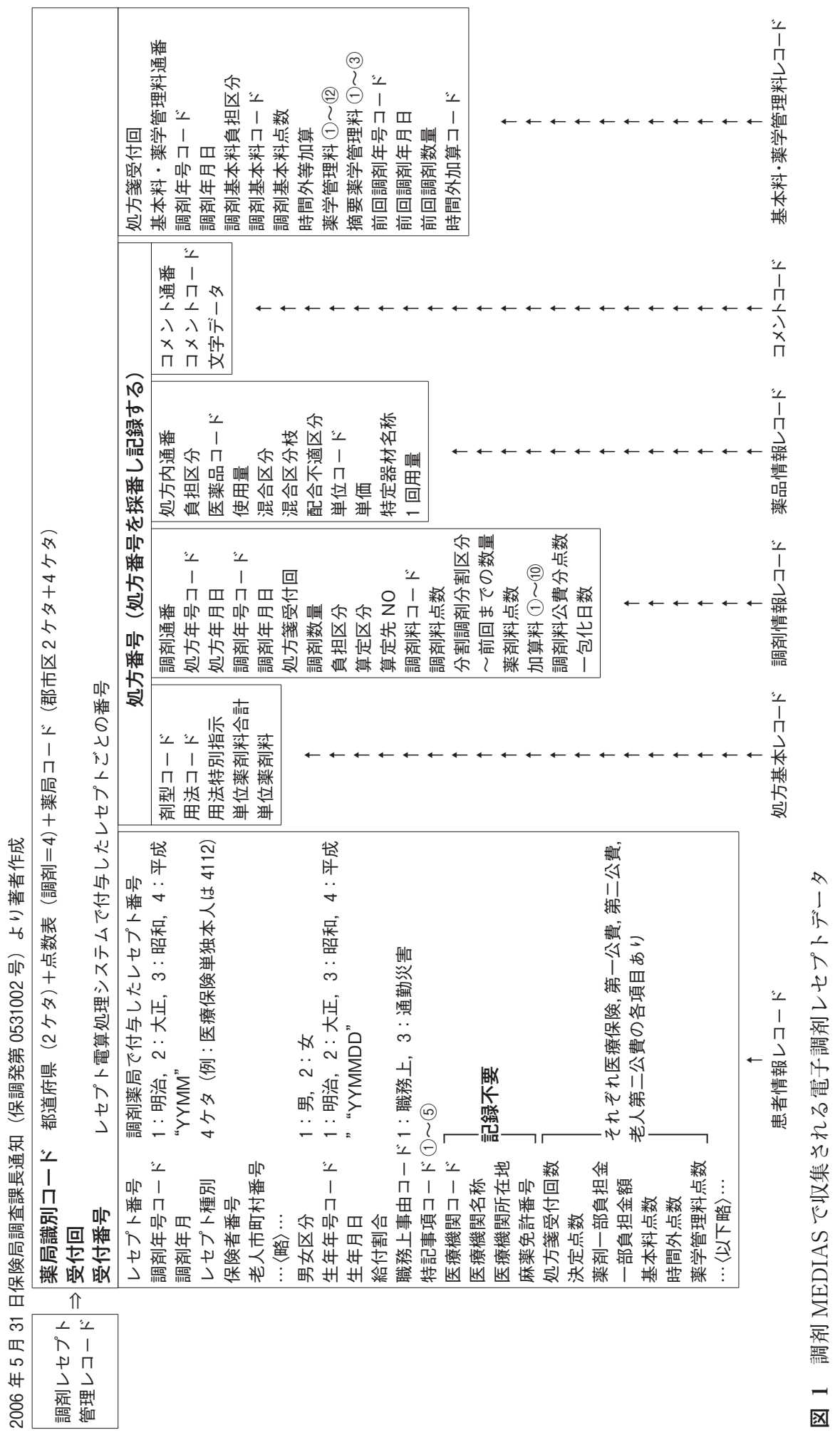




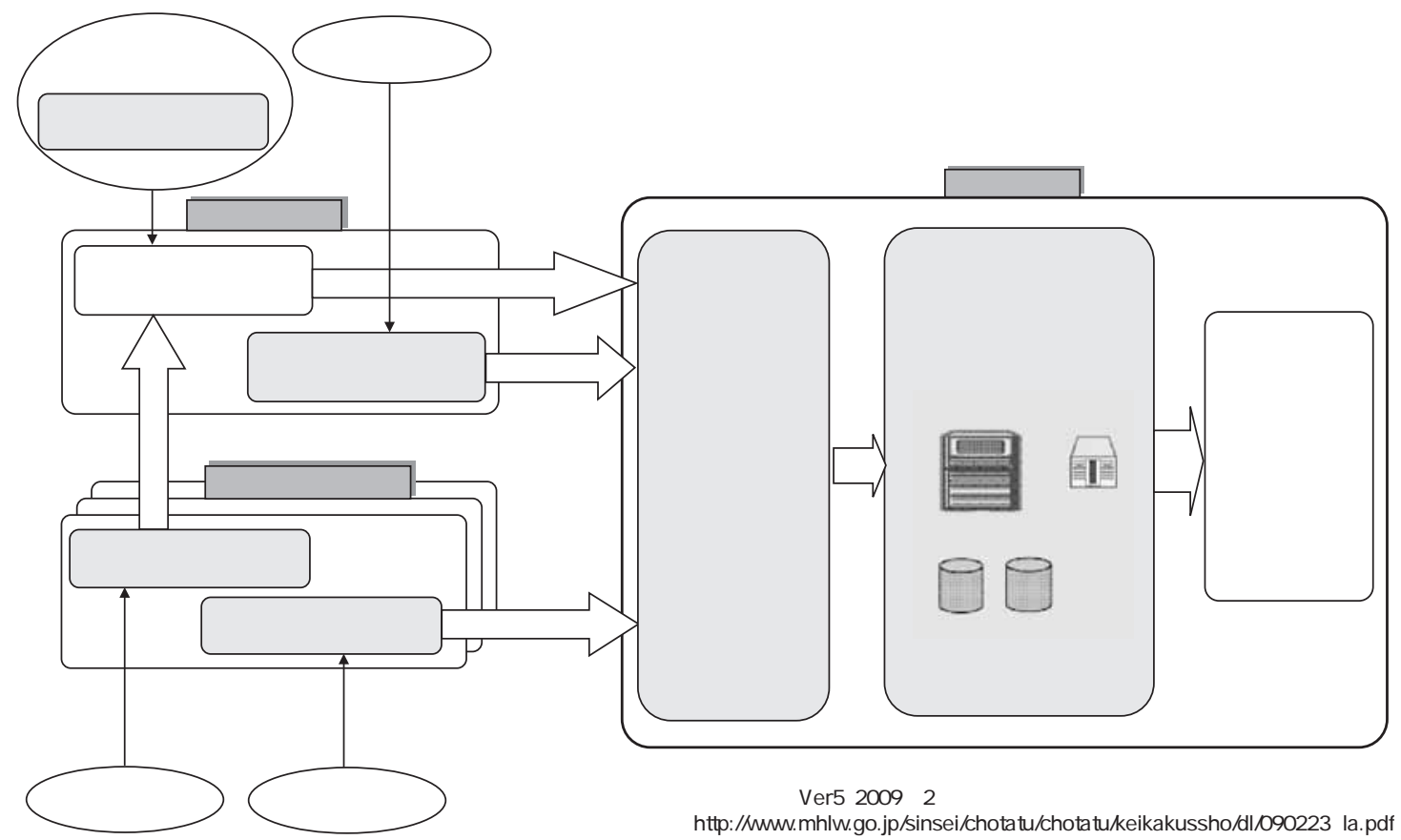

図 2 レセプト情報・特定健診情報等データベースシステム（仮称）イメージ図

ソフトウェア（システム開発）ならびに工程管理 の 3 つに分けて 2008 年度中に行われる (表).

匿名化・提供システムは, 氏名等の個人情報を 削除しつつも，同一人を追跡可能にする暗号シス テムであり，審査支払機関ならびに約 500 の保険 者に配布される。取込・定型資料作成等システム は，与える条件〔都度に入力する SQL（Structured Query Language）等〕に基づいてデータを 抽出・集計する。分析については, 抽出したデー 夕をもとにして, 厚生労働省各課クライアント端 末で必要に応じて実施する。

システムが完成した 2009 年度以降は「保守・運 用」業務を委託し, 電子レセプトと特定健康診査 等データの収集・蓄積を開始する。保守・運用業 者の役務は業務運用手順書に定められ，1）デー夕 取达（支払基金および国保連合会から受け取った 媒体よりデー夕を取込み, 名寄せ処理を行う), 2) 空口業務（厚労省担当職員からのデータ集計・出 力依頼を受ける)，3）デー夕集計・出力 (2 日以内 に集計・出力デー夕を媒体にて担当職員に搬送す
る. 月 10 件程度を想定), 4) マスターメンテナン ス（担当職員より光媒体で随時提供されるマス ターを取り込み更新する）等である。データベー スの機器（サーバー等）は厚労省の建物内ではな く保守・運用業者が用意する「東京都内またはそ の近郊の震度 6 強に対して倒壊および崩壊しない ことを保証する」場所に設置される。

レセプト完全オンライン化が達成される 2011 年度以前と以降とで第 1 , 第 2 フェーズに区切り, 第 1 フェーズ（2009～10 年）では蓄積した情報を 用いて分析方法を確立, 第 2 フェーズでは第 1 フェーズで確立した分析方法を定型化することで 業務を効率化するとともに，さらに高度な情報の 利活用のために BI (Business Intelligence) 等の データ分析ッールの導入も検討し, システムの機 能拡張等を 2009 年度以降に検討する。

医療費適正化計画は 2008～2012 年度の 5 力年 計画であるが, 中間年の 2010 年度に進渉状況評 価が予定されており，これがNDBの当面の最大 の活用目的となる。この進渉状況評価は, その結 
表 レセプト情報・特定健診情報等データベース調達案件の全容

\begin{tabular}{|c|c|c|c|c|}
\hline 決定日 & 業務内容 & 受注企業 & 金額 & 仕様書案のサイト* \\
\hline 2007 年 9 月 2 日 & 仕様書(案)の作成及び技術的支援 & アクセンチュア株式会社 & $41,895,000$ & \\
\hline 2008 年 8 月 20 日 & 工程管理 & アクセンチュア株式会社 & $79,436,700$ & \\
\hline 2008 年 11 月 20 日 & システム開発 & 富士通株式会社 & $72,450,000$ & 080529-1.html \\
\hline 2009 年 2 月 12 日 & 機器調達 & $\begin{array}{l}\text { 富士電気 ITソリュー } \\
\text { ション株式会社 }\end{array}$ & $446,250,000$ & 080912-1.html \\
\hline 2009 年 3 月 23 日 & システム運用・機器等保守 (5 年間) & & & 081113-1.html \\
\hline
\end{tabular}

*http://www.mhlw.go.jp/sinsei/chotatu/chotatu/shiyousho-an/

果いかんによっては特定健康診査・保健指導のあ り方も大きく見直される可能性がある.

第 1 フェーズでの分析内容は，ア）医療費適正 化計画の目標達成状況，イ）健診・保健指導情報 の都道府県別（地域別）実施状況，ウ）医療費に 及ぼす影響に関する分析（レセプト情報と健診・ 保健指導情報を紐付け，医療費との関係を評価） の 3 つが想定されている。とりわけ健診・保健指 導の実施率ならびにメ夕ボ該当者（=特定保健指 導対象者）の減少率は, 保険者の 2013 年度以降の 後期高齢者医療制度への支援金の増減にはねかえ るだけに重要性は大きい。

ウ）の医療費への影響については, 医療費適正 化計画の直接の評価指標とはされていないもの の, 特定健診・保健指導の導入の目的がメタボ該 当者の減少による医療費の長期的な抑制にあるこ とから, 同一人の長期的な追跡による評価が必要 であろう。また，医療費適正化計画のもうひとつ の柱である, 新医療計画における 4 疾病 5 事業の 評価等もNDBの重要な使命といえよう.

\section{医療給付実態調査}

$\mathrm{NDB}$ 構築が着々と進むなか, いささか重複のき らいもあるが, 2008 年 4 月診療分より毎月全レセ プト〔医, 歯, 調剤, DPC (Diagnosis-ProcedureCombination)]の限定された項目について保険局 調査課が全保険者（および広域連合）よりレセプ トデータ収集を開始しているので付言する。「医 療給付実態調查」という名称のこの調査はNDB と同様, 高齢者医療確保法第 16 条 1 項を根拠に
行われ統計法の適用は受けない.これに伴って 1955 年より毎年実施されてきた国民健康保険医 療給付実態調査は 2008 年をもって中止された ${ }^{3)}$.

収集される項目は，医療機関コード（医，歯， 薬は 3 桁目の点数表番号で区別), 診療科 (旧総合 病院のみ), 保険者番号, 被保険者記 - 番号 (変換 ツールにて整理番号に変換), 生年月日, 性別, 処 理年月, 診療年月, 本人家族入外（医科レセプト はこれで入院と外来を区別), 入院年月日 (入院以 外はすべて 0), 診療実日数, 決定点数, 食事. 生 活回数, 食事・生活決定基準額, 疾病コード (119 分類. 原則, 毎月記録だが, 特定月診療分のみで も可）と，限定されたものである ${ }^{4)}$.

健康保険や共済組合については直接調査課に磁 気媒体により提出し, 国保については, 都道府県 または国保連合会がとりまとめて提出する。健康 保険組合はすでに 1,500 組合中, 1,000 以上の組 合が電子レセプトについては支払基金より全内容 の提供を受けている。 そのため「フォーマット変 換ツール」によって上記の必要項目のみ抽出し, 紙レセプトについては上記の項目を入力し「整理 番号変換ツール」で被保険者記・番号を整理番号 に変換して提供する（フォーマット変換ツールは 記・番号の整理番号への変換ツールを含んでい る) ${ }^{5)}$.

新しい医療給付実態調查は, 歯科レセプトのよ うに電子化がほとんど進んでいないレセプトにつ いては必要であろうが，調剤レセプトのようにす でに $90 \%$ 以上電子化されているレセプトについ ては重複であり, 必要性は疑わしい。調剤 ME- 
DIAS では，電子調剤レセプトの大半の情報を収 集しているのに，医療給付実態調查ではそのうち 限られたデー夕のみを重複して収集するからであ る。医科レセプトでも，傷病情報は，電子レセプ 卜に記載される ICD10 分類の可能なコードでは なく 119 分類の粗いものであり，しかも毎月では ないとなれば，傷病データとしての価值も限られ る、総じて医療給付実態調査は，まだ紙レセプト が残るまでの間, 全数を把握するための「つなぎ」 的な意義はあるといえる。

\section{まとめ}

わが国の NDB は，世界にも例のない大規模な ものであり, 有効に活用されれば計り知れないメ リットをもたらす。それゆえ「医療費適正化計画 の作成，実施，評価」という狭い目的に限定せず, 公益目的に積極的な活用が望まれるし，また構築 されるシステムはそうした広汎な活用に十分対応 できるものである。とりわけ薬剤疫学的な面での 有効活用の可能性は大きく, 学会の意見書と要望
書6) の内容が十分に反映されるよう会員の支援と 努力を期待する.

\section{文献}

1）月刊基金 $2009 ； 50$ （3）：49.（シンポジウム後の最新 デー夕に更新した)

2）岡本悦司.「医療サービスの質の向上等のためのレ セプト情報等の活用に関する検討会」報告書の解説. 薬剤疫学2008；13（1）: 17-19.

全文は以下のサイト参照．http://www.mhlw.go.jp/ shingi/2008/01/s0130-16.html

3）指定統計・承認統計・届出統計月報. 第 56 巻 7 号 (2008 年 7 月)

4) 厚労省保険局調查課長事務連絡. 医療給付実態調查 の報告要領について。保調発第 0428003 号 (2008 年 4 月 28 日）別紙 1.

5）事務連絡文書や変換ツールは以下のサイトよりダウ ンロードできる. http://www.mhlw.go.jp/bunya/ iryouhoken/iryouhoken10/

6）レセプトデータベース特別委員会.レセプトデータ ベースの活用による医薬品の安全確保のための実効 性あるシステム構築に向けて。薬䯕疫学 $2008 ; 13$ (1) : 11-15. 